\title{
POLIMORFISMUL MANIFESTĂRILOR CLINICE ÎN BOALA CELIACĂ LA COPIL
}

\author{
Laura Mihaela Trandafirr ${ }^{1}$, Eugen Cîrdeiu' ${ }^{1}$, Carmen Oltean ${ }^{1}$, Doina Mihăilă ${ }^{2}$, \\ Dana-Teodora Anton-Păduraru ${ }^{1}$

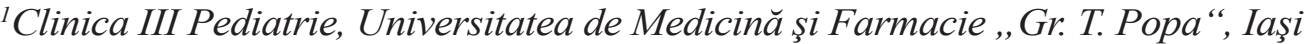 \\ ${ }^{2}$ Laboratorul de Anatomie Patologică, \\ Spitalul Clinic de Urgență pentru Copii ,Sf. Maria“, Iaşi
}

\begin{abstract}
REZUMAT
Boala celiacă $(B C)$ reprezintă o afecțiune sistemică autoimună produsă prin sensibilizarea la gluten la pacienții cu predispoziție genetică. Manifestările clinice ale BC sunt extrem de variate, de la sindromul tipic de malabsorbție intestinală (caracterizat prin diaree cronică, meteorism abdominal şi malnutriție) la simptome atipice care pot afecta orice sistem sau organ: constipație cronică, hepatocitoliză persistentă, anemie refractară la tratamentul cu fier, dureri abdominale recurente, afecțiuni neurologice, defect al smalțului dentar. Autorii prezintă patru pacienți de vârstă pediatrică diagnosticați cu diferite forme atipice de boală celiacă: forma cu dureri abdominale recurente, cu sindrom de hepatocitoliză şi forma cu constipație cronică, toate însoțite de falimentul creşterii şi un caz de diabet zaharat tip I asociat cu boală celiacă. În concluzie, este necesară cunoaşterea tuturor formelor clinice ale bolii celiace de către medicul pediatru, gastroenterolog şi medicul de familie pentru a diagnostica boala la vârsta copilăriei şi, astfel, să prevină complicațiile pe termen lung, respectiv osteoporoza, infertilitatea si limfomul intestinal.
\end{abstract}

Cuvinte cheie: boală celiacă, manifestări clinice, diabet zaharat tip I, copil

Boala celiacă (BC) reprezintă o afecțiune multisistemică autoimună declanşată de ingestia de gluten şi prolaminele înrudite la pacienții cu predispoziție genetică care poate afecta orice organ sau sistem, cu un spectru larg de manifestări clinice de severitate variabilă (1).

Clasic, BC a fost considerată o afecțiune pediatrică manifestată prin semne şi simptome gastrointestinale tipice datorate malabsorbției intestinale şi reprezentate de diaree cronică, meteorism abdominal, anorexie, falimentul creşterii. Introducerea testelor serologice de screening (anticorpi antigliadină, anti-endomisium, anti-transglutaminază tisulară, anti-gliadină deamidată) a permis identificarea tuturor formelor de BC: atipice, silențioase sau latente, precum şi identificarea bolii la patologii asociate. Deoarece de multe ori se manifestă prin simptome atipice (dureri abdominale recurente, constipație, anemie refractară la tratamentul cu fier, sindrom de citoliză hepatică, artrită etc.) sau este clinic asimptomatică, BC poate trece nediagnosticată sau se poate complica dacă expunerea la gluten continuă. Cunoaşterea tuturor formelor de manifestare a BC este necesară pentru diagnosticarea la timp, înainte de apariția complicațiilor care afectează calitatea vieții acestor pacienți sau chiar pun în pericol viața (limfomul intestinal).

În prezent se cunoaşte faptul că debutul BC poate fi întâlnit la orice vârstă, de la sugar la vârstnic, realizând un tablou clinic polimorf datorat în principal componentei autoimune. Astfel, vă prezentăm o serie de cazuri clinice în care $\mathrm{BC}$ s-a manifestat prin afectare hepatică, constipație, dureri abdominale recurente şi un caz în care debutul BC $\mathrm{s}-\mathrm{a}$ asociat cu cel al diabetului zaharat de tip 1 (DZ tip 1).

\section{Observația clinică I}

Pacient de sex masculin (F. A.), în vârstă de 5 ani şi 2 luni, internat în Clinica III Pediatrie a Spitalului Clinic de Urgență „Sf. Maria“ din Iaşi pentru 
inapetență, dureri abdominale recurente, stagnarea creșterii ponderale. În primii doi ani de viaţă copilul a avut o creștere staturo-ponderală normală. La internare prezenta stare generală relativ bună, $G=$ $13 \mathrm{~kg}, \mathrm{~T}=119 \mathrm{~cm}, \mathrm{IMC}$ (indice de masă corporală) $=9,2$, pulmonar şi cardiac normal stetacustic, inapetență, abdomen suplu, depresibil, dureros spontan şi la palpare periombilical, tranzit intestinal fiziologic, dar au atras atenția tulburările de comportament (copil irascibil, introvertit, care nu $\mathrm{s}$-a adaptat în colectivitate). Investigațiile biologice au evidențiat absența sindromului inflamator, anemie hipocromă microcitară feriprivă $(\mathrm{Hb}=10 \mathrm{~g} \%$, $\mathrm{VEM}=70 \mu 3, \mathrm{HEM}=28,5 \mathrm{pg}, \mathrm{CHEM}=36 \%$, Fe seric $=25 \gamma \%$ ), iar anticorpii anti-transglutaminază tisulară (ATGT) IgA şi IgG au fost prezenţi la un titru patologic de 53,5 UI/1, respectiv 13,4 UI/1. Prezența HLA DQ2 a susținut diagnosticul de BC. Sub regim fără gluten evoluția clinico-biologică a fost favorabilă, cu reluarea apetitului, dispariția durerilor abdominale, curbă ponderală lent ascendentă şi dispariția tulburărilor de comportament. Anticorpii ATGT s-au negativat după 6 luni de regim fără gluten $(1,5 \mathrm{UI} / 1)$. După 8 luni de regim fără gluten $\mathrm{G}$ a fost de $18 \mathrm{~kg}, \mathrm{~T}=121 \mathrm{~cm}$ şi $\mathrm{IMC}=12,3$.

\section{Observația clinică II}

Pacientă în vârstă de 1 an şi 6 luni, din mediul rural (județul Botoşani), s-a internat în Clinica III Pediatrie a Spitalului Clinic de Urgență „Sf. Maria“ din Iaşi pentru falimentul creşterii. Din antecedente reținem că este al doilea copil, născut la termen, pe cale naturală $(\mathrm{Gn}=3.100 \mathrm{gr})$, alimentată natural 2 luni, ulterior cu formulă de lapte praf adaptat vârstei (Morinaga). Alimentația complementară a fost inițiată la vârsta de 4 luni, cu introducerea glutenului în alimentație la 5 luni. Antecedentele personale patologice au atras atenția asupra falimentului creşterii debutat la vârsta de 9 luni. La examenul clinic obiectiv al pacientei s-a observat stare generala relativ bună, având $\mathrm{G}=9 \mathrm{~kg},-2,15$ DSG (deviații standard pentru greutate) şi $\mathrm{T}=83 \mathrm{~cm},-1,03 \mathrm{DST}$ (deviații standard pentru talie), scăzute în raport cu percentilele normale corespunzătoare categoriei de vârstă. Investigațiile paraclinice au identificat absența sindromului inflamator, anemie microcitară hipocromă feriprivă $(\mathrm{HB}=9,3 \mathrm{~g} \%, \mathrm{VEM}=68 \mu 3$, $\mathrm{HEM}=23,3$ pg, $\mathrm{CHEM}=34,6 \%$, Fe seric $=30 \gamma \%$ ), sindrom de citoliză hepatică cu valori ale transaminazelor de trei ori mai mari decât valoarea normală $(\mathrm{TGP}=83 \mathrm{UI} / 1, \mathrm{TGO}=92 \mathrm{UI} / \mathrm{l})$. În vederea stabilirii etiologiei sindromului de citoliză hepatică s-au determinat AgHBs - negativ, anticorpi anti- virus hepatitic C-negativi, anticorpi anti-citomegalovirus-negativi. Anticorpii anti-gliadină au prezentat valori patologice - $18 \mathrm{UI} / 1$ (VN sub 6 UI/1). Biopsia intestinală duodenală (Fig. 1) a evidențiat atrofie vilozitară totală, infiltrat inflamator limfoplasmocitar în corion, numeroase limfocite intraepiteliale în lamina propria (MARSH IIIC).

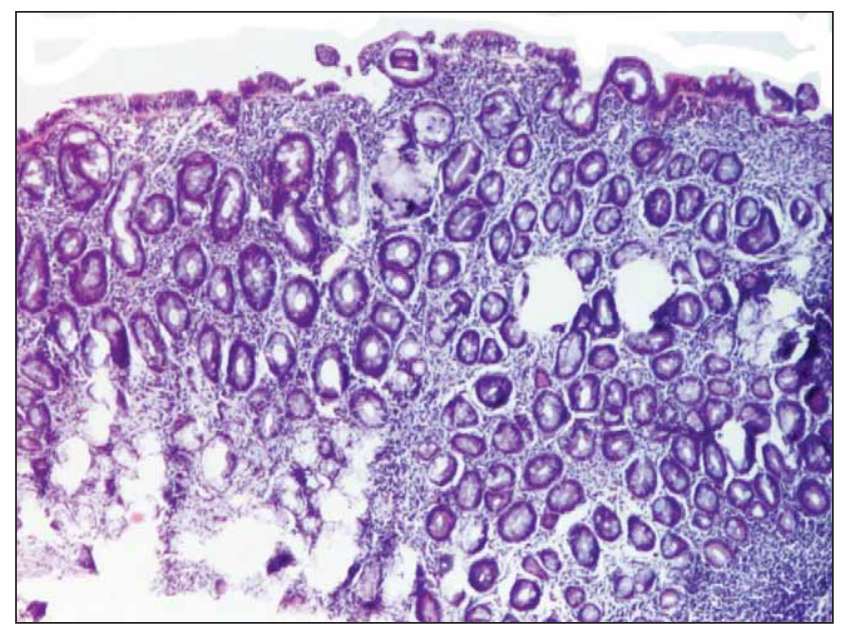

FIGURA 1. Atrofie vilozitară totală, infiltrat inflamator limfoplasmocitar în corion, numeroase limfocite intraepiteliale în lamina propria (MARSH IIIC)

Diagnosticul pozitiv a fost de $\mathrm{BC}$ asociată cu hepatopatie reactivă şi anemie feriprivă. În urma dietei fără gluten, curba ponderală a fost ascendentă, iar valorile TGP, TGO s-au normalizat după 6 luni de regim fără gluten.

\section{Observația clinică III}

Pacient de sex masculin, în vârstă de 1 an şi 2 luni, internat in Clinica III Pediatrie a Spitalului Clinic de Urgență „Sf. Maria“ din Iaşi pe data de 31 august 2006 pentru falimentul creşterii şi constipație cronică. Examenul clinic la internare a evidențiat stare generală relativ bună, hipotrofie ponderală $(\mathrm{G}=7,5 \mathrm{~kg}, \mathrm{~T}=76 \mathrm{~cm}, \mathrm{IP}=0,68)$, tegumente palide, țesut celular subcutanat redus pe abdomen, torace, membre, sechele de rahitism (bose frontale, torace evazat la baze, mătănii costale), hipotonie musculară, inapetență, abdomen mărit de volum, tranzit intestinal încetinit (un scaun de consistență crescută la interval de 4-5 zile). Testele de laborator au evidențiat prezența anticorpilor antigliadină tip IgAcu valori de $38 \mathrm{UI} / 1$ (VN sub $6 \mathrm{UI} / 1$ ). Radiografia de pumn a evidențiat vârstă osoasă întârziată corespunzătoare vârstei cronologice de 8 luni. Examenul endocrinologic a exclus hipotiroidismul congenital (TSH, freeT4 - valori normale, ecografia de tiroidă normală). În urma biopsiei intestinale duo-denale, examenul antomopatologic a evidențiat (Fig. 2): atrofie vilozitară subtotală, infiltrat imflamator 
limfo-plasmocitar în corion, numeroase limfocite intraepiteliale în lamina propria - aspect sugestiv pentru MARSH IIIB. Diagnosticul pozitiv stabilit în acest caz a fost BC formă atipică cu constipație şi malnutriție protein-calorică de gradul II. Ca urmare a instituirii dietei fără gluten, curba ponderală a fost ascendentă, tranzitul intestinal s-a reluat, iar valorile anticorpilor antigliadină tip $\operatorname{IgA}$ s-au normalizat după 3 luni de regim fără gluten.

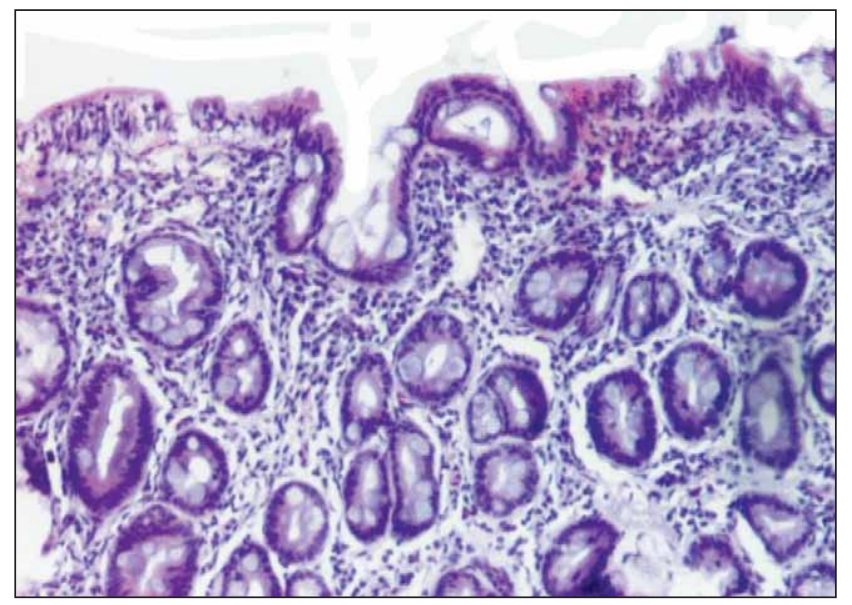

FIGURA 2. Atrofie vilozitară subtotală, infiltrat inflamator limfo-plasmocitar în corion, numeroase limfocite intraepiteliale în lamina propria (MARSH IIIB)

\section{Observația clinică IV}

Pacient în vârstă de 9 ani şi 7 luni se internează în Clinica III Pediatrie a Spitalului Clinic de Urgență „Sf. Maria“ din Iaşi pentru stare generală influenţată şi meteorism abdominal. La internare copilul prezenta stare generală influențată, $G=34 \mathrm{~kg}$, $\mathrm{T}=141 \mathrm{~cm}$, indice de masă corporală (IMC) = 17,17, abdomen mărit de volum, ficat cu marginea inferioară la $3 \mathrm{~cm}$ sub rebordul costal de consistență normală (hepatomegalie), meteorism abdominal postprandial şi inconstant dureri abdominale difuze, scaune cu mucus şi resturi alimentare nedigerate, zone de depigmentare cutanată la nivelul membrelor superioare şi inferioare. Investigațiile paraclinice au evidențiat: absența sindromului inflamator, glicemie $=207 \mathrm{mg} \%(\mathrm{VN}<120 \mathrm{mg} \%), \mathrm{HbAlc}=$ $13,53 \%(\mathrm{VN}<6 \%)$, glicozurie prezentă $=150 \mathrm{mg} /$ dl şi corpi cetonici + , colesterol $=202 \mathrm{mg} / \mathrm{dl}$, trigliceride $=98 \mathrm{mg} \%$, proteine totale $=59,51 \mathrm{~g} / \mathrm{l}$, albumine $=29 \mathrm{~g} / \mathrm{l}$, anticorpii ATGT Ig A $>200 \mathrm{U} / \mathrm{ml}$ şi Ig G $=35,6 \mathrm{U} / \mathrm{ml}(\mathrm{VN}<20 \mathrm{UI} / \mathrm{ml})$. După efectuarea endoscopiei digestive superioare cu biopsie intestinală duodenală, examenul anatomopatologic a identificat (Fig. 3) duodenită cronică masivă cu atrofie vilozitară parțială, sugestiv pentru diagnosticul de BC MARSH III A.

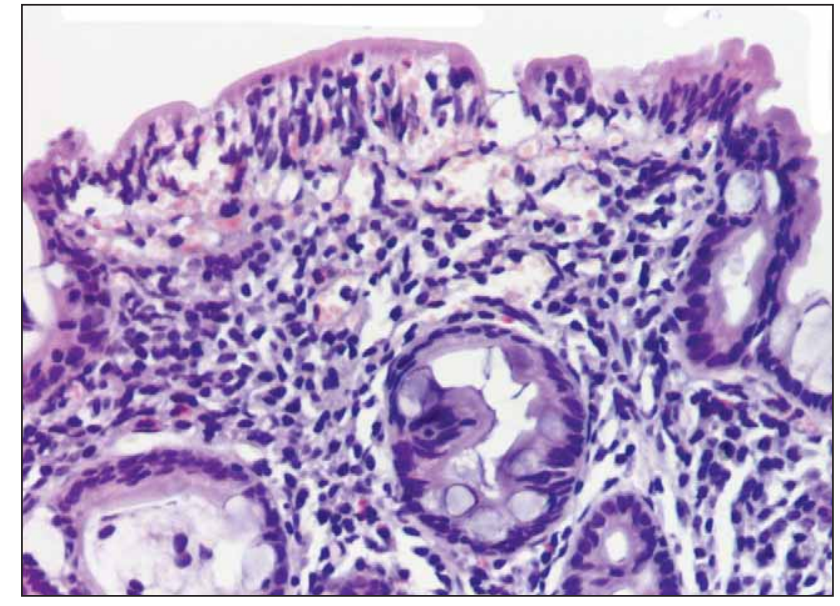

FIGURA 3. Duodenită cronică masivă cu atrofie vilozitară parțială (MARSH IIIA)

Diagnosticul pozitiv în acest caz a fost de DZ tip I la debut asociat cu BC. Managementul terapeutic în acest caz a vizat atât dieta fără gluten, cât şi management propriu al DZ tip I cu instituirea insulinoterapiei.

\section{DISCUȚII}

Autorii au prezentat patru cazuri clinice de BC manifestată prin dureri abdominale recurente, afectare hepatică, constipație şi un caz în care debutul BC s-a asociat cu cel al DZ tip 1 . S-a observat că indiferent de manifestările clinice (constipație, dureri abdominale recurente) sau biologice (sindrom de citoliză hepatică, hiperglicemie cu glicozurie) retardul creşterii a fost prezent la toți pacienții.

Primele descrieri despre BC provin de la Arataeus din Cappadochia din secolul I Î.Hr., iar ulterior, în 1888, Samuel Gee a observat că boala se întâlneşte la copiii cu vârsta cuprinsă între 1 şi 5 ani şi este determinată de o eroare din dieta copiilor. În ciuda descrierii tabloului clinic al bolii, Gee nu a stabilit legătura finală dintre BC şi ingestia de gluten (On the Coeliac Affection, 1888) (2,3). În anii 1940, Willem Karen Dicke a observat rolul grâului şi al cerealelor înrudite în declanşarea simptomelor $\mathrm{BC}$ şi a recomandat primul şi încă unicul tratament al BC, regimul fără gluten (4).

BC este diagnosticată la orice vârstă, de la sugar la adult, manifestările clinice ale bolii variind în funcție de vârsta de debut. Manifestările clinice se corelează mai ales cu vârsta pacientului la momentul debutului bolii, de multe ori nefiind interpretate ca evocatoare pentru această afecțiune (5).

Debutul clasic în BC la copil are loc în jurul vârstei de 18 luni, după săptămâni sau chiar luni de la introducerea cerealelor în alimentație. La copilul mic debutul $\mathrm{BC}$ este insidios, prin scaune de tip 
steatoric, păstoase, lucioase, decolorate, voluminoase, cu resturi alimentare nedigerate. Triada clasică cu diaree cronică steatoreică, abdomen mărit de volum şi malnutriție este din ce în ce mai rar întâlnită, în prezent fiind din ce în ce mai frecvent descrise formele atipice (2). Dintre manifestările atipice la pacienții noştri au fost întâlnite durerile abdominale recurente care au întârziat diagnosticul până la vârsta de 5 ani, în timp ce constipația şi sindromul de citoliză hepatică asociate cu malnutriția au fost diagnosticate în al doilea an de viață. Debutul precoce, în perioada de sugar, se caracterizează prin vărsături şi scaune apoase cu evoluție trenantă. Bolnavii pot prezenta în evoluție episoade recurente de diaree severă, cu scaune apoase și deshidratare severă, respectiv criză celiacă, din ce în ce mai rar întâlnită în prezent. După vârsta de 3-5 ani, locul debutului prin manifestările digestive este luat de stagnarea creşterii în greutate, ulterior şi a taliei. La copilul mare, BC este una dintre principalele cauze de hipotrofie staturo-ponderală prin anorexie, malabsorbție şi pierderi intestinale de nutrienți. Toți pacienții incluşi în studiu au prezentat întârzierea creşterii. La tulburările de creştere se asociază anorexia, durerile abdominale recurente, constipația, astenia fizică marcată şi modificările neuro-comportamentale (copil apatic, introvertit, sau, din contra, irascibil, nemulțumit, uneori devenind şi violent, cu scăderea concentrării şi a randamentului şcolar). Consecințele malabsorbției intestinale sunt reprezentate de crizele de tetanie hipocalcemică, osteopenie cu osteoporoză, fracturi spontane ale oaselor lungi (malabsorbția vitaminei D şi a calciului), nevrite de tip Beri-Beri, glosită, stomatită, cheilită, paloare tegumentară (malabsorbția vitaminelor din grupul B), echimoze, epistaxis, sângerări gingivale şi intestinale (malabsorbția vitaminei K), precum şi dermatoze si distrofii ale firului de păr (malabsorbția vitaminei A). Defectul smalțului dentar, ulcerațiile aftoase recurente, erupția dentară întârziată, cheilita, lichenul plan oral, glosita atrofică, xerostomia sunt manifestări orale ale BC care, recunoscute la timp, permit stabilirea precoce a diagnosticului (6).

Deşi în prezent există o tendință de debut tardiv a BC la copiii cu vârsta cuprinsă între 5 şi 7 ani, în unele cazuri pacienții sunt depistați târziu, în adolescență sau chiar la vârsta adultă (3). Adolescenții cu BC prezintă întârziere în maturația sexuală, hipo- sau amenoree, consecințe ale impactului bolii asupra creşterii şi dezvoltării. Diagnosticarea BC la vârsta adultă se caracterizează prin consecințele îndelungate ale malabsorbției intestinale (anemie refractară la tratamentul cu fier, carențe de acid folic, vitamine şi minerale), la care se adaugă infertilitatea, dermatita herpetiformă, artrita şi artralgia (frecvent sunt afectate articulațiile coloanei lombare, articulaţia şoldului şi a genunchiului). Datele din literatură demonstrează creşterea ratei afecțiunilor maligne, inclusiv limfomul intestinal, carcinomul esofagian cu celule scuamoase, melanomul şi adenocarcinomul la pacienții cu BC în comparație cu populația generală $(7,8)$.

$\mathrm{BC}$ recunoaşte următoarele forme clinice (adaptat după clasificarea OSLO - 2013):

- forma clasică manifestată prin semne şi simptome datorate malabsorbției intestinale: diaree cronică cu steatoree, falimentul creşterii, meteorism abdominal, anorexie, criză celiacă.

- forma non-clasică cuprinde atât simptome gastrointestinale, dar care nu se datorează malabsorbției intestinale (dureri abdominale recurente, vărsături, constipație, sindrom de colon iritabil), cât şi simptome extra-intestinale (sindrom de citoliză hepatică, anemie refractară la tratament, stomatită aftoasă recurentă, hipotrofie staturală, defect al smalțului dentar, hipogonadismul şi pubertate întârziată, artrită, dermatită herpetiformă, epilepsie cu calcificări intracraniene, ataxie, autism, depresie). Aceşti pacienți sunt, de obicei, monosimptomatici sau oligosimptomatici.

- forma subclinică, cunoscută anterior ca $B C$ silențioasă sau asimptomatică, în care pacientul este asimptomatic, dar mucoasa intestinală prezintă leziuni intestinale specifice. Tot în această categorie este inclusă şi forma latentă a BC definită prin existența mucoasei intestinale normale la copiii care primesc gluten în alimentaţie şi care vor dezvolta boala manifestă clinic ulterior din cauza predispoziției genetice (singura modificare la nivelul mucoasei intestinale întâlnită este creşterea limfocitelor intraepiteliale) (2). Această formă nu prezintă semne sau simptome clinice suficiente pentru a iniţia testarea serologică pentru BC în practica de rutină.

- forma potențială (,potential coeliac disease") în care pacienții prezintă biopsie intestinală normală, dar care au un risc crescut de a dezvolta $\mathrm{BC}$, risc susținut de serologie pozitivă $(15,16)$.

- forma refractară caracterizată prin faptul că pacienţii prezintă semne şi simptome persistente sau recurente de malabsorbție intestinală cu atrofia vilozităţilor intestinale, fără ca acestea să fie ameliorate de respectarea strictă a 
dietei fără gluten pe o perioadă mai mare de 12 luni.

- sensibilitatea la gluten non-celiacă se caracterizează prin una sau mai multe manifestări clinice, imunologice sau morfologice declanşate de ingestia de gluten la persoanele la care $\mathrm{BC}$ a fost exclusă; această categorie poate include alergia alimentară mediată non- $\operatorname{IgE}(9)$.

BC se asociază cu o serie de boli autoimune (DZ tip I, tiroidita autoimună, sindromul Sjörgen, psoriazis, alopecia areată) sau non-autoimune (deficitul selectiv de IgA, sindromul Down, sindromul Williams, sindromul Turner, nefropatia cu IgA, afecțiuni neuro-psihiatrice de tipul autism, depresie, ataxie, epilepsie cu calcificări intracraniene), rudele de gradul I ale pacienților cu BC (3).

Asocierea DZ tip I cu BC este foarte bine documentată şi susţinută de predispoziția genetică comună. S-a observat că unii pacienți cu DZ tip 1 prezintă episoade de hipoglicemie simptomatică cu diminuarea progresivă a necesarului de insulină, aparent nejustificată prin reducerea aportului nutritiv sau intensificarea activității fizice, înaintea stabilirii diagnosticului de BC. Apariţia hipoglicemiei şi diminuarea necesarului de insulină pot sugera BC activă la bolnavii cu diabet sau complianță scăzută la regimul fără gluten la pacienții deja diagnosticați. Manifestările gastrointestinale tipice întâlnite în BC (diaree, distensie abdominală) sunt rar întâlnite la pacienții diabetici, predominând semnele şi simptomele atipice, izolate (anemia sideropenică, hipotrofia staturală, pubertatea întârziată, epilepsia, hipertransaminazemia, simptomele dispeptice, dermatita herpetiformă sau stomatită aftoasă recurentă) $(10)$.

Testele imunologice de screening (anticorpi anti-gliadină, anti-endomisium, anti-transglutami- nază tisulară, anti-gliadină deamidată) sunt recomandate grupurilor populaţionale cu risc (rude de gradul I ale pacienților cu BC, sindroame de malabsorbție oligo sau paucisimptomatice, boli asociate). De asemenea, se utilizează în scop diagnostic pentru limitarea necesității efectuării biopsiei mucoasei intestinale şi pentru monitorizarea evoluţiei BC sub tratament şi verificarea complianţei la regimul fără gluten. Conform recomandărilor ESPGHAN, biopsia intestinală la copiii cu simptome tipice este posibil să nu se efectueze dacă titrul anti-transglutaminază tisulară IgA este mai mare de 10 ori decât limita superioară a normalului şi prezintă predispoziție pentru genotipul HLA specific BC. Introducerea testelor serologice de screening a arătat că $\mathrm{BC}$ este în prezent mult mai frecventă decât se credea inițial, prevalența fiind de $1 \%$ în populația generală $(11,12)$. Diagnosticarea pacienților folosind testele de screening a evidențiat creşterea incidenței formelor atipice sau silenţioase, în timp ce forma clasică, cu diaree, este în scădere $(13,14)$.

\section{CONCLUZII}

Cazuistica prezentată scoate în evidență întârzierea diagnosticului de $\mathrm{BC}$ din cauza formelor atipice şi a patologiilor asociate. Utilizarea testelor imunologice la copiii cu manifestări atipice sau ca metodă de screening la grupele de risc a determinat creşterea incidenței formelor atipice sau silențioase la copilul mare şi adolescent. Cunoaşterea polimorfismului manifestărilor clinice a BC permite diagnosticarea precoce şi previne apariția complicaţiilor pe termen lung: osteoporoza, infertilitatea, limfomul intestinal. 